\title{
KEABSAHAN PENYIDIKAN BADAN NARKOTIKA NASIONAL (BNN)
}

\author{
Oleh: \\ Made Dwi Kurniahartawan ${ }^{1}$
}

\begin{abstract}
This study is a Normative Legal Research wich move from existence void of legal norms or principles of law. Emptiness legal norms in this study contained in the provisions of Article 6 and Appendix class I, II , and III of the Invitation No. 35 of 2009 Concerning Narcotics. New psychoactive Narcotics Substances (NPS) are not already in the list of various types of narcotics as well as groups and derivatives within the provisions of Law No. 35 of 2009 Concerning Narcotics in conjunction with Government Regulation No. 44 Year 2010 Concerning Narcotics Precursor. New psychoactive Narcotics Substances (NPS) in case one of them contained Raffi Ahmad. This study also discusses the validity of the authority of the narcotic crime investigation by the National Narcotics Board ( $B N N$ ) assessed pursuant to Presidential Decree No. 23 of 2010 on the National Narcotics Board. The approach used is the approach of legislation, the legal analytical \& conseptual approach and the the case approach. The conclusion of this research is the validity of the investigative authority of the National Narcotics Board (BNN) to dealers in narcotic crime is not invalid because the National Narcotics Board established pursuant to Presidential Decree No. 23 of 2010 with reference to Article 149 of Law No. 35 of 2009 Concerning Narcotics. The validity of the investigation of the National Narcotics Board ( BNN) to the case Raffi Ahmad is not valid and can not be criminally accountable for non-compliance of the elements of criminal liability in particular the objective elements of nature can be punished for not strictly regulated in terms oflegislation applicable in accordance with the principle of legality.
\end{abstract}

Keywords : Authority Investigations , Narcotics, National Narcotics Board

\begin{abstract}
Abstrak
Penelitian ini merupakan penelitian Hukum Normatif yang beranjak dari adanya kekosongan norma atau asas hukum. Kekosongan norma hukum dalam penelitian ini terdapat dalam ketentuan Pasal 6 dan lampiran golongan I, II, dan III Undang-Undang Nomor 35 Tahun 2009 tentang Narkotika. Narkotika New Psikoaktif Substances (NPS) belum diatur dalam daftar berbagai jenis golongan serta turunannya dalam ketentuan Undang-undang Nomor 35 Tahun 2009 tentang Narkotika juncto Peraturan Pemerintah Nomor 44 Tahun 2010 Tentang Prekursor Narkotika. Narkotika New Psikoatif Substances (NPS) salah satu jenisnya terdapat dalam kasus Raffi Ahmad. Penelitian ini juga membahas keabsahan penyidikan Badan Narkotika Nasional (BNN) dalam tindak pidana narkotika dikaji berdasarkan Keputusan Presiden Nomor 23 Tahun 2010 tentang Badan Narkotika Nasional. Pendekatan yang digunakan adalah pendekatan perundang-undangan,

\footnotetext{
Mahasiswa Magister Ilmu Hukum Universitas Udayana, Denpasar, Bali, Alamat: Perumahan Geriya Tansa Trisna Jl. Cendana, No. 42, Kecamatan Kuta Utara, Kabupaten Badung, Bali, e-mail: Dwikhartawan@yahoo.com
} 
pendekatan analitis \& konseptual hukum dan pendekatan kasus. Kesimpulan dari penelitian ini adalah keabsahan kewenangan penyidikan Badan Narkotika Nasional (BNN) dalam tindak pidana narkotika adalah tidak sah karena Badan Narkotika Nasional dibentuk berdasarkan Keputusan Presiden Nomor 23 Tahun 2010 dengan mengacu pada Pasal 149 UU Nomor 35 Tahun 2009 tentang Narkotika. Keabsahan wewenang penyidikan Badan Narkotika Nasional (BNN) dalam kasus Raffi Ahmad adalah tidak sah dan tidak bisa dipertanggungjawabkan secara pidana karena tidak terpenuhinya unsur pertanggung jawaban pidana khususnya unsurunsur obyektif yakni perbuatannya dapat dihukum karena tidak diatur secara tegas dalam ketentuan undang-undang dan bertentangan dengan asas legalitas.

Kata Kunci: Badan Narkotika Nasional, Narkotika, Keabsahan Penyidikan

\section{PENDAHULUAN}

\section{I.1 Latar Belakang}

Perkembanganilmupengetahuan serta tekhnologi dengan cepatnya dewasa kini, membawa pengaruh pada berkembangnya narkotika jenis baru yaitu New Psychoactive Substances. Beraneka ragam narkotika jenis baru yang beredar dimasyarakat salah satunya adalah berjenis Chatinon. Narkotika jenis ini terdapat didalam kasus Raffi Ahmad.

Narkotika jenis baru ini terjadi disebabkan adanya rekayasa obatanobatan yang dilakukan oleh Bandar Narkotika dengan memodifikasi struktur kimianya dengan tujuan untuk melepaskan diri dari jerat hukum mengingat jenis narkotika yang termasuk kedalam klasifikasi New Psychoactive Substances belum diatur dalam daftar berbagai jenis golongan Narkotika yang diatur dalam ketentuan Pasal 6 serta lampiran golongan narkotika pada Undang-Undang No. 35 Tahun 2009 Tentang Narkotika. ${ }^{2}$

Badan Narkotika Nasional, 2013,ZatPsikoaktif Baru (New Phsycoactive Substances-NPS), Alvalaible at http:/bnnp-diy.com/posting-117narkoba-baru-nps.html. Diakses 22 November 2013
Selain permasalahan yang terdapat pada hal diatas, dalam penelitian ini juga terdapat permasalahan lain berkaitan dengan keabsahan kewenangan penyidikan Badan Narkotika Nasional yang dibentuk berdasarkan Peraturan Presiden Nomor 23 Tahun 2010 tentang Badan Narkotika Nasional mengacu pada ketentuan Pasal 67 Undang-Undang No. 35 Tahun 2009 Tentang Narkotika.

\section{I.2 Perumusan Masalah}

1. Bagaimanakah keabsahan kewenangan penyidikan Badan Narkotika Nasional (BNN) terhadap pengedar dalam tindak pidana narkotika?

2. Apakah absah penyidikan Badan NarkotikaNasional(BNN)dalam kasus narkotika Raffi Ahmad dikaji berdasarkan ketentuan Undang-Undang No. 35 Tahun 2009 tentang Narkotika?

\section{I.3 Tujuan Penelitian}

Untuk

mendeskripsikan

dan melakukan analisis secara 
komperhensif tentang keabsahan kewenangan penyidikan Badan Narkotika Nasional (BNN) terhadap pengedar dalam tindak pidana narkotika serta mengetahui keabsahan penyidikan Badan Narkotika Nasional (BNN) dalam kasus Raffi Ahmad berdasarkan ketentuan UndangUndang No. 35 Tahun 2009 tentang Narkotika.

\section{METODE PENELITIAN}

Penelitian ini menggunakan metode penelitian hukum normatif dengan beranjak dari adanya kekosongan norma hukum. ${ }^{3}$ Pendekatan dalam penelitian ini menggunakan pendekatan perundangundangan, pendekatan analisis konsep hukum dan pendekatan kasus. Bahan hukum yang digunakan terdiri dari bahan hukum primer, bahan hukum sekunder, dan bahan hukum tersier.

\section{HASIL DAN PEMBAHASAN}

\subsection{Keabsahan Kewenangan}

Penyidikan Badan Narkotika Nasional Terhadap Pengedar Dalam Tindak Pidana Narkotika.

Mengacu pada teori kewenangan dalam domain hukum administrasi negaradikenaltiga sumberkewenangan pemerintah. Sumber kewenangan pemerintah dapat diperoleh dengan cara atribusi, delegasi, dan mandat.

Jhony Ibrahim, 2005, Teori \& Metodelogi Penelitian Hukum Normatif" Surabaya, hlm. 284.
Atribusi merupakan wewenang pemerintahan yang diberi oleh pembuat undang-undang ditunjukan untuk organ pemerintah. ${ }^{4}$

Delegasi ialah diserahkannya wewenang kepada pemerintahan dari suatu badan atau pejabat pemerintah kepada badan atau pejabat pemerintah yang lain. ${ }^{5}$ Ketika wewenang telah diserahkan, pemberi wewenang tidak mempunyai wewenang lagi.

Mandat ialah wewenang yang didapat dari atribusi maupun delegasi serta bisa dimandatkan kepada badan atau pegawai bawahan dalam hal pejabat yang mendapat wewenang tidak bisa melakukan sendiri. Lain halnya dengan delegasi, pada mandat, pemberi mandat tetap memiliki wewenang untuk mengerjakan sendiri wewenangnya. Sesuai kehendaknya ia dapat memberi petunjuk kepada mandataris mengenai apa yang dikehendakinya. Pemberi mandat secara hukum tetap bertanggung jawab atas untuk perbuatan yang dilakukan mandataris. ${ }^{6}$ Wewenang dalam konsep hukum publik terdiri dari beberapa hal, yaitu:

a. Pengaruh;

b. Dasar hukum;

c. Konformitas hukum.

Komponen pengaruh adalah penggunaan wewenang digunakan dengan maksud untuk mengendalikan perilaku subjek hukum.

\footnotetext{
$4 \quad$ Irfan Fachrudin, 2004, Pengawasan Peradilan Administrasi Terhadap Tindakan Pemerintah, Alumni, Bandung, hlm. 49. Irfan Fachrudin, ibid, hlm. 51 Irfan Fachrudin, ibid, hlm. 53
} 
Komponen dasar hukum adalah penggunaan wewenang harus memiliki dasar hukum.

Komponen konformitas adalah wewenang memiliki standarisasi yakni adanya standar umum (semua jenis wewenang) dan standar khusus (untuk jenis wewenang tertentu). ${ }^{7}$

Undang-Undang No. 35 Tahun 2009 tentang Narkotika yang memberikan wewenang penyidikan Badan Narkotika Nasional (BNN) melalui Peraturan Presiden Nomor 23 Tahun 2010 Tentang Badan Narkotika Nasional, dalam kajian teori kewenangan dan karakteristik undang-undang administrasi bersanksi pidana hal tersebut adalah tidak sah. Dengan sifat karakteristik administrasi bersanksi pidana yang didalamnya memuat ketentuan tentang pelabelan narkotika, perijinan narkotika untuk kesehatan dan pengadaan prekursor narkotika, pembentukan Badan Narkotika Nasional hendaknya harus melalui undang-undang dengan mengacu pada ketentuan Pasal 7 UU No. 48 Tahun 2009 tentang Kekuasaan Kehakiman menyatakan bahwa kekuasaan yang sah adalah aparat penegak hukum yang memiliki kewenangan melakukan penyelidikan dan penyidikan dengan mengacu pada undang-undang.

Penulis mengutip pendapat Prajudi Atmosudirjo dengan pemikirannya yang memberikan

Phillipus M. Hadjon, 1997, Tentang Wewenang, Yuridika, hlm.1. penjelasannya berkaitan dengan kewenangan dan wewenang :

Kewenangan adalah kekuasaan formal bersumber dari kekuasaan legislatif (diberi oleh undangundang) atau dari kekuasaan eksekutif/administratif. Wewenang adalah kekuasaan untuk membuat tindakan hukum publik. $^{8}$

Khusus bagi kewenangan dalam penyidikan memiliki komponen konformitas, yakni adanya standar wewenang khusus dan spesifik. Penulis mengutip dan mengelaborasi pendapat Prajudi Atmosudirjo berpandangan bahwa kekuasaan yang sah adalah kekuasaan bersumber dari kekuasaan legislatif (diberi oleh undangundang).

Agar kewenangan penyidikan Badan Narkotika Nasional sah hendaknya dibentuk melalui peraturan pelaksana seperti Peraturan Pemerintah (PP). Dalam konsep undang-undang administrasi bersanksi pidana Undang-Undang No. 35 Tahun 2009 Tentang Narkotika tidak dapat mendelegasikan kewenangannya. Hal ini merupakan kesalahan dalam cara memperoleh wewenang dibentuknya Badan Narkotika Nasional (BNN) dengan mengacu pada ketentuan Pasal 67 Undang-Undang No. 35 Tahun 2009 Tentang Narkotika.

8 Prajudi Atmosudirjo, 1981, Hukum Administrasi Negara, Ghalia Indonesia, hlm. 29. 
Tindakan yang menyalahi wewenang tolak ukurnya adalah :

a. Terdapatnya penyalahgunaan wewenang dapat dinilai dari ada dan tidaknya pelanggaran yang terdapat dalam peraturan yang tertulis atau nilai kepatutan yang ada dalam masyarakat dan negara.

b. Asas kepatutan dalam hal melaksanakan ditetapkan jika tidak ada peraturan dasar. ${ }^{9}$

Tindak Pidana Narkotika adalah tindak pidana umum bukan tindak pidana khusus yang memiliki akibat tertentu atau diterapkan untuk orang tertentu yang tidak dapat dilakukan oleh orang lain. Sehingga tidak boleh ada penyimpangan terhadap hukum pidana materiil dan pidana formiil dalam hal ini KUHP dan KUHAP dan tunduk pada pasal 103 KUHP kecuali sepanjang tidak diatur didalam perundang-undangan lainnya dan KUHAP telah menentukan secara tegas pada Pasal 6 KUHAP bahwa Penyidik adalah pejabat Polri dan PPNS (Pejabat Pegawai Negeri Sipil) tertentu yang diberikan wewenang secara khusus oleh undang-undang.

Terbentuknya Perpres No. 23 Tahun2010mengenaiBadanNarkotika Nasional (BNN) terkait adanya UU. No. 35 Thn 2009 tentang Narkotika

Indrianto Seno Adji dalam Nur Basuki Minarno, 2009, Penyalahgunaan Wewenang Dan Tindak Pidana Korupsi Dalam Pengelolaan Keuangan Daerah, Laksbang Mediatama, Palangkaraya, hlm.75 yang memiliki karakteristik tersendiri yakni menganut hukum administrasi bersanksi pidana. Selain mengatur tentang sanksi pidana kejahatan narkotika yang diatur dalam ketentuan Pasal 111-148 juga mengatur urusan dalam rangka pelaksanaan tugas pemerintah sehingga undang-undang ini memiliki karakteristik tersendiri yakni BNN bertanggung jawab secara langsung kepada Presiden dan dilengkapi dengan adanya Peraturan Mentri Kesehatan (Permenkes) yang diatur dalam ketentuan Pasal 11 serta Pasal 50 berkaitan dengan kebutuhan pengadaan prekursor narkotika dalam industri farmasi.

Negara Indonesia menganut sistem hukum eropa kontinental yang berdasar pada paham Rechtstaat. Hal ini dijelaskan oleh Julius Stahl yang didalamnya terdapat beberapa hal yaitu:

a. Perlindungan hak asasi manusia;

b. Pembagian kekuasaan;

c. Pemerintahan berdasarkan undang-undang;

d. Peradilan tata usaha negara. ${ }^{10}$

Konsep Rechtstaat dalam negara hukum mengharuskan tindakan pemerintah mengacu pada undangundang. Konsep Rechstaat memiliki relevansi langsung terhadap legalitas terbentuknya sebuah institusi negara.

\footnotetext{
10 Bahder Johan Nasution, 2011, Negara Hukum dan Hak Asasi Manusia, cetakan pertama, CV. Mandar Maju, Bandung, hlm. 3.
} 
3.2. Analisis Kasus Raffi Ahmad Tentang Keabsahan Penyidikan Badan Narkotika Nasional (BNN) Mengacu Pada Ketentuan UU No. 35 Thn 2009 Tentang Narkotika.

Secara pendekatan peraturan perundang-undangan (The statute Approach) ${ }^{11}$ kasus Raffi Ahmad merupakan bentuk berkembangnya jenis narkotika baru yang terjadi diakibatkan adanya rekayasa obatobatan oleh Bandar narkotika untuk menghindar dari jerat hukum dengan merubah struktur kimianya dan masuk kedalam klasifikasi narkotika jenis New Psychoactive Substances. Badan Narkotika Nasional (BNN) mendapatkan Narkotika berjenis Cathinone pada saatpenangkapan Raffi Ahmad. Senyawanya adalah dengan struktur dasar 3,4 Methylene Dioxy Me thcathinon (Methylone). Narkotika ini berbahaya apabila dikonsumsi dengan berlebihan menyebabkan psikoaktif dan bagi yang memakai tidak sesuai takaran berdampak pada terjadinya overdosis, kejang, keram, dan berakhir dengan meninggal dunia. ${ }^{12}$ Narkotika jenis Methylone ini tidak diatur secara tegas didalam UU No. 35 Tahun 2009 Mengenai Narkotika.

Dalam konsep hukum pidana dikenal adanya ketentuan asas legalitas. Pasal 1 KUHP menentukan bahwa perbuatan tidak bisa dituntut

11 H. Zainudin Ali, 2010, Metode Penelitian Hukum, Sinar Grafika, Jakarta, hlm.24.

12 Badan Narkotika Nasional (BNN), 2013, locit secara pidana apabila tidak ada pengaturan yang tegas dalam suatu undang-undang. Apa yang terkandung didalam makna asas legalitas memiliki makna yang jelas dan tegas sebagai suatu barometer dalam domain hukum pidana. Eksistensi Asas legalitas secara mendasar dengan mengelaborasi Teori Sistem Hukum Hart berarti aturan mana yang dapat di anggap sah (rules of recognition), Kedua; bagaimana dan oleh siapa dapat diubah (rules of change) dan ketiga; bagaimana dan oleh siapa dapat dikuatkan, dipaksakan/ ditegakan (rules of ajudication). ${ }^{13}$

H.L.A. Hart pada teorinya Teori Sistem Hukum dalam pemikirannya membagi sistem hukum menjadi dua yaitu primary rules dan secondary rules. Hal tersebut merupakan pusat dari sistem hukum dan harus ada. Primery rules adalah mengatur tentang kewajiban manusia dalam tindakannya serta apa yang tidak diperbolehkan. ${ }^{14}$

Pada primary rules ada dua model. Jenis pertama yang didalamnya terdapat norma sosial yang keberadaannya dengan dipenuhinya beberapa persyaratan; Pertama adanya peraturan keseragaman perilaku didalamkelompokmasyarakat(umum). Kedua, peraturan itu dirasa sebagai kewajiban dalam suatu (sebagian besar) dalam anggota kelompok sosial yang relevan. ${ }^{15}$

\footnotetext{
13 H.L.A. Hart, 1961, The Concept of law, Oxford University Press, Oxford, p. 96 Ibid

$15 \quad$ Ibid, h. 96-99
} 
Model kedua disebut Hart dengan secondary rules adalah aturan tentang aturan yang bila di rinci meliputi :

1. Peraturan yang menetapkan dengan tegas peraturan mana yang dapat di anggap sah.

2. Dengan siapa dan dalam hal bagaimana dapat dirubah.

3. Dengan siapa dan bagaimana dapat dikuatkan,dipaksakan/ ditegakan. ${ }^{16}$

Hukum Pidana mensyaratkan untuk dapat dipidananya suatu delik harus memenuhi usnsur pertanggungjawaban pidana dan syarat pemidanaan. Keabsahan penyidikan Badan Narkotika Nasional (BNN) terhadap kasus Raffi Ahmad adalah tidak sah dan tidak dapat dipertanggung jawabkan secara pidana sesuai dengan konsep hukum pidana yang menganut doktrin asas legalitas serta tidak terpenuhinya unsur-unsur pertanggung jawaban pidana khususnya unsur obyektif yakni sifat dapat dihukum karena tidak diatur secara tegas didalam ketentuan undang-undang yang berlaku dan sesuai dengan asas lex certa pembuat undang-undang (legislatif) harus merumuskan secara jelas dan rinci mengenai perbuatan yang disebut dengan tindak pidana (kejahatan)

Pembentuk undang-undang harus mendefinisikan dengan spesifik perbuatan pidana yang diancam oleh undang-undang (nullum crimen

$16 \quad$ Ibid sine lege stricta), sehingga tidak ada rumusan norma yang tidak jelas dalam undang-undang berkaitan dengan norma dan sanksi. ${ }^{17}$

Unsur pertanggungjawaban pidana oleh Moeljatno didefinisikan tindak pidana adalah tidak dijinkannya perbuatan oleh undang-undang yang didalamnya terdapat larangan sanksi pidana kepada setiap orang yang melanggar ketentuannya. Pelarangan untuk perbuatan dimaksudkan kepada perbuatan yang dilakukan oleh seseorang dan ancaman pidana dimaksudkan kepada seseorang yang mengakibatkan adanya tindak pidana. Beberapa hal yang harus ada tentang dapat dipertanggungjabawabkannya suatu perbuatan pidana :

a. Tindakan dan efek (perbuatan);

b. Hal atau situasi yang mengikuti perbuatan;

c. Situasi tambahan yang memperberat pidana;

d. Sifat melawan hukum yang objektif.

e. Sifat melawan hukum yang subjektif. ${ }^{18}$

Sedangkan berkaitan dengan syarat pemidanaan suatu perbuatan pidana haruslah memenuhi kriteria:

17 Roelof H. Heveman, 2002, The Legality of Adat Criminal Law in Modern Indonesia, Tata Nusa, Jakarta, hlm. 50.

18 Moeljatno pada Johny Krisnan, 2008, Sistem Pertanggungjawaban Pidana Dalam Perspektif Pembaharuan Hukum Pidana Nasional, (tesis) Program Studi Magister (S2) Ilmu Hukum Pasca Sarjana Universitas Diponegoro Semarang, hlm. 22. 
a. Adanya kesalahan serta bertentangan dengan hukum. (Actus Reus).

b. Perbuatan yang pertanggung jawabannya diatur dalam ketentuan Hukum Pidana. (Mens Rea).

Meurut Indrianto Senoadji dalam negara hukum yang mnganut karakteristik anglo-saxon, unsur pemidanaan adalah terpenuhinya syarat actus reus dan mens rea. Oleh karna itu dalam penerapan sanksi pidana harus digunakan unsur sifat melawan hukum formal yaitu ditentukan atau tidaknya perbuatan tersebut dalam ketentuan peraturan perundang-undangan yang berlaku. ${ }^{19}$

Bagir Manan dalam pandangannya menjelaskan hal terpenting suksesnya hukum ditegakan terdapat pada tata cara hukum ditegakan (procedural justice) dan substansi/hasil hukum yang ditegakan oleh penegak hukum (substantive justice).${ }^{20}$ Tata cara tersebut adalah tata cara untuk mencapai keadilan dalam penegakan hukum. Keadilan hanya dapat diwujudkan dengan prosedur yang adil. Proses penegakan hukum

Indrianto Seno Adji dalam Marwan EfFendy, 2012, Kapita Selekta Hukum Pidana : Perkembangan Isu-Isu Aktual Dalam Kejahatan Finasial Dan Korupsi, Referensi, Jakarta, hlm. 84.

20 Bagir Manan, 2005, Penegakan Hukum Yang Berkeadilan dalam Varia Peradilan, Tahun ke-XX, Nomor 241, Ikatan Hakim Indonesia (IKAHI), Jakarta, hlm. 10. dapat juga berupa penerapan diskresi yang tidak diatur didalam ketentuan perundang-undangan dengan tegas dan didalamnya terdapat penilaian pribadi. ${ }^{21}$

\section{PENUTUP}

\subsection{Simpulan}

1. Keabsahan kewenangan penyidikan Badan Narkotika Nasional (BNN) terhadap pengedar dalam tindak pidana narkotika adalah tidak sah karena Badan Narkotika Nasional dibentuk berdasarkan Peraturan Presiden No. 23 Tahun 2010 dengan mengacu pada Pasal 149 Undang-Undang No. 35 Tahun 2009 tentang Narkotika. Sebagai Undang-Undang Administrasi bersanksi pidana yang memuat tentang pelabelan narkotika dan tatacara pengadaan prekursor narkotika UndangUndang No. 35 Tahun 2009 Tentang Narkotika tidak dapat mendelegasikan kewenangan pembentukan Badan Narkotika Nasional. Badan Narkotika Nasional hendaknya dibentuk melalui peraturan pelaksana seperti peraturan pemerintah.

2. Keabsahan penyidikan Badan Narkotika Nasional (BNN) terhadap kasus Raffi Ahmad adalah tidak sah dan tidak

21 Soerjono Soekanto, 2008, Faktor-faktor Yang Mempengaruhi Penegakan Hukum, PT. Raja Grafindo Persada, Jakarta, hlm. 7. 
dapat dipertanggung jawabkan secara pidana karena tidak terpenuhinya unsur-unsur pertanggungjawaban pidana khususnya unsur obyektif yakni sifat dapat dihukum karena belum diatur secara tegas didalam Undang-undang Narkotika No. 35 Thn 2009. Hal ini sejalan dengan asas legalitas dan asas lex certa. Pembuat undang-undang (law maker) harus merumuskan dengan tegas dan spesifik perbuatan yang dikatakan sebagai tindak pidana.

\subsection{Saran}

1. Disarankan bagi para legislator yakni Dewan Perwakilan Rakyat (DPR) bersama presiden jika masih menghendaki adanya Badan Narkotika Nasional hendaknya membentuk suatu undang-undangagarmemberikan kewenangan yang sah kepada Badan Narkotika Nasional dalam penyidikan tindak pidana narkotika.

2. Untuk mengantisipasi perkembangan prekursor narkotika dan narkotika jenis baru disarankan bagi para legislator yakni Dewan Perwakilan Rakyat (DPR) bersama Presiden untuk merevisi Undang-Undang No. 35 Tahun 2009 tentang Narkotika serta membentuk suatu klausula pasal yang menyatakan bahwa penyidikan tindak pidana narkotika yang jenisnya tidak tencantum didalam ketentuan peraturan perundang-undangan tentang klasifikasi golongan beserta turunannya bahwa penyidikan dapat dilakukan berdasarkan hasil uji laboratorium forensik. Klausula ini berfungsi untuk mengantisipasi perkembangan kejahatan narkotika melalui rekayasa obat-obatan yang diciptakanuntuk menghindardari sanksi hukum dan memberikan sifat yang lebih progresif dari suatu perundang-undangan.

\section{DAFTAR PUSTAKA}

\section{Buku}

Ali, H. Zainudin, 2010, Metode Penelitian Hukum, Sinar Grafika, Jakarta.

Atmosudirjo, Prajudi 1981, Hukum Administrasi Negara, Ghalia Indonesia.

Fachrudin, Irfan 2004, Pengawasan Peradilan Administrasi

Terhadap Tindakan Pemerintah, Alumni, Bandung.

M. Hadjon, Phillipus, 1997, Tentang Wewenang, Yuridika.

H.L.A. Hart, 1961, The Concept of law, Oxford University Press, Oxford.

Manan, Bagir 2005, Penegakan Hukum Yang Berkeadilan dalam Varia Peradilan, Tahun keXX, Nomor 241, Ikatan Hakim Indonesia (IKAHI), Jakarta. 
Ibrahim, Jhony, 2005, Teori \& Metodelogi Penelitian Hukum Normatif, Surabaya.

Johan Nasution, Bahder, 2011, Negara Hukum dan Hak Asasi Manusia, cetakan pertama, CV. Mandar Maju, Bandung.

Seno Adji, Indrianto dalam Efendy, Marwan, 2012, Kapita Selekta Hukum Pidana: Perkembangan Isu-Isu Aktual Dalam Kejahatan Finasial Dan Korupsi, Referensi, Jakarta.

Seno Adji, Indrianto dalam Minarno, Nur Basuki, 2009, Penyalahgunaan Wewenang Dan Tindak Pidana Korupsi Dalam Pengelolaan Keuangan Daerah, Laksbang Mediatama, Palangkar

Soekanto, Soerjono, 2008, Faktorfaktor Yang Mempengaruhi Penegakan Hukum, PT. Raja Grafindo Persada, Jakarta.

\section{Tesis}

Moeljatno dalam Krisnan, Johny ,2008, Sistem Pertanggungjawaban Pidana Dalam Perspektif Pembaharuan Hukum Pidana Nasional, (tesis) Program Studi Magister (S2) Ilmu Hukum Pasca Sarjana Universitas Diponegoro, Semarang.

\section{Internet}

Badan Narkotika Nasional, 2013, Zat Psikoaktif Baru (New Phsycoactive Substances-NPS),
Alvalaible at http://bnnp-diy. com/posting-117-narkoba-barunps.html, Diakses 22 November 2013 